\title{
Doelmatige zorg: wat leren we de aios?
}

In de rubriek (Ver)Stand van zaken geeft de aiotho (arts-in-opleiding tot huisarts-onderzoeker) een korte samenvatting van de literatuur die heeft geleid tot de belangrijkste onderzoeksvraag waarop hij aan het promoveren is. De coördinatie van de rubriek is in handen van: N. Rasenberg, Erasmus MC, aiotho en redactielid H\&W - Correspondentie: n.rasenberg@erasmusmc.nl

\section{PRAKTIJKVRAAG}

Wanneer moet er een controle gepland worden? Is er aanvullend onderzoek nodig? Moet dit nu of kan het ook later? Artsen wegen in de dagelijkse praktijk voortdurend kosten voor het gezondheidssysteem en kansen op gezondheidswinst tegen elkaar af. Hiermee hebben zij een belangrijke invloed op de zorgkwaliteit en -kosten. Hoe leren medisch studenten, arts-assistenten en artsen 'doelmatige zorg' te leveren en hoe kunnen (huisarts)praktijken en opleidingen dit leerproces optimaliseren?

\section{HUIDIG BELEID}

In de huidige basisopleiding is er geen gestructureerd onderwijs dat zich op 'doelmatige zorg' richt. De vraag is of gestructureerd onderwijs over dit onderwerp überhaupt nodig is. In de dagelijkse praktijk maken artsen immers voortdurend afwegingen op het gebied van doelmatige zorg, waarbij zij streven naar een optimale balans tussen kosten en baten.

Wel is het door de toenemende mogelijkheden voor diagnostiek en behandelingen voor de individuele arts lastig vast te stellen welke middelen in het grote en veranderende aanbod potentieel schadelijk en duur zijn. Wanneer de positieve effecten van een nieuw middel twijfelachtig of klein zijn, is de vraag of de kwaliteit van de zorg in het geding is. Het voorbereiden van artsen op het afwegen van maatschappelijke verantwoordelijkheid, professionele integriteit en wensen van patiënten is een taak van de opleiding. Onderzoek is nodig om opleidingen te informeren hoe ze dit kunnen doen.

\section{RELEVANTIE VOOR DE HUISARTS}

Als huisarts heb je een coördinerende en adviserende rol, waarbij het leveren van 'doelmatige zorg' een kerntaak is. De groeiende substitutie, de samenwerking met het ziekenhuis en nauwe betrokkenheid bij de ouderenzorg zorgen ervoor dat huisartsen regelmatig in aanraking komen met de dillema's rond doelmatige zorg. De langdurige arts-patiëntrelatie geeft huisartsen mogelijkheden om mét patiënten te bespreken waar persoonlijke en medische grenzen liggen. De combinatie van een gedegen arts-patiëntrelatie en de coördinatie van het vervolgtraject maakt dat huisartsen zich bewust zijn van de consequenties van hun beslissingen voor mens en maatschappij. Daarnaast hebben huisartsen relatief veel zicht op de kosten van de zorg. Veel huisartsen die momenteel werkzaam zijn, zijn opgeleid in een tijd waarin patiënten minder mondig waren en er beperkte technologische en therapeutische mogelijkheden waren. Huisartsen ervaren de complexiteit van 'doelmatige zorg' en zijn op zoek naar handvatten voor in de praktijk.

\section{STAND VAN ZAKEN IN DE LITERATUUR}

Naar schatting wordt er in de Amerikaanse zorg ongeveer $30 \%$ verspild. ${ }^{1}$ Ook in Nederland is er een groeiend besef dat een deel van het zorgbudget niet ten goede komt aan de kwaliteit van de zorg. Het elimineren van verspilling is een manier om de kwaliteit van de zorg te verhogen en de stijgende zorgkosten te remmen. Dit heeft gunstige effecten op de toegankelijkheid en betaalbaarheid van de zorg.

Onderzoek laat zien dat scholing zich dient te richten op drie deelgebieden. Het eerste deelgebied is kennis, waarbij kennis over kosten, richtlijnen en patiëntvoorkeuren aan bod komen. Het tweede deelgebied is reflective practice. Hierbij krijgen artsen (in opleiding) inzicht in hun eigen praktijkvoering en worden er kritische vragen over nut en nutteloosheid gesteld. Het laatste deelgebied betreft de ondersteunende leeromgeving, waarin normen en waarden van de beroepsgroep worden doorgegeven. De leeromgeving wordt vormgegeven door collega's en andere zorgprofessionals en is van grote invloed op het leerproces. ${ }^{2}$ Het is nog onduidelijk hoe artsen in de dagelijkse praktijk ondersteund kunnen worden ten aanzien van doelmatige zorg.

\section{CONCLUSIE}

Onderzoek laat zien dat verspilling in de zorg de kwaliteit en kosten van de zorg bedreigt. Het is dus van belang dat medisch studenten, arts-assistenten en artsen 'doelmatige zorg' leren te leveren aan hun patiënten. Kennis over het leerproces kan de verdere ontwikkeling van het onderwijs ondersteunen.

\section{BELANGRIJKSTE ONDERZOEKSVRAAG}

Hoe leren medisch studenten, arts-assistenten en artsen doelmatige zorg te leveren en hoe kunnen de werkplekken en opleidingen dit leerproces optimaliseren?

\section{LITERATUUR}

1 Berwick DM, Hackbarth M. Eliminating waste in US health care. JAMA 2012;307(14):1513-6.

2 Stammen LA, Stalmeijer RE, Paternotte E, Oudkerk Pool A, Driessen EW, Scheele F, et al. Training physicians to provide high-value, cost-conscious care. A systematic review. JAMA 2015;314(22):2384-2400. 